\title{
Formation, vegetation succession and acidification of a Mid-Holocene moorland pool in the western Netherlands
}

\author{
B. van Geel ${ }^{1, *}, 0$. Brinkkemper ${ }^{2}$, E.J. Weeda ${ }^{3}$ \& J. Sevink ${ }^{1}$
}

\author{
1 Institute for Biodiversity and Ecosystem Dynamics, University of Amsterdam, Science Park 904, 1098 XH Amsterdam, the Netherlands \\ 2 Cultural Heritage Agency of the Netherlands, P.0. Box 1600, 3800 BP Amersfoort, the Netherlands \\ 3 Veerallee 28, 8019 AC Zwolle, the Netherlands \\ * Corresponding author. Email: B.vanGeel@UvA.nl
}

Manuscript received: 31 July 2015, accepted: 24 December 2015

\section{Abstract}

We studied a Holocene peat fill of a small depression in Pleistocene coversand, in the western border zone of Het Gooi, to assess the early local and regional vegetation history in relation to sea-level rise, soil development and potential human impact. In the fourth millenium $\mathrm{BC}$, a podzol which had formed in the depression became stagnative, leading to the development of a moorland pool. The local vegetation changed from dry heathland, through an amphibic vegetation type with, among others, Littorella uniflora and Lycopodiella inundata, to a permanently moist Sphagnum-dominated vegetation. The existence of moorland pools and the development of such habitats into Sphagnum-dominated vegetation are known from Late-Holocene anthropogenic, more or less open landscapes that were formed on a podzolising sandy soil under ericaceous vegetation. However, the recorded vegetation succession did not show any recognisable local human impact and therefore is attributed to natural succession. In the period concerned, sea level was still about $4 \mathrm{~m}$ below the land surface in the depression, implying that water logging occurred independent from a rise in sea level and associated groundwater level. It took until the Late Middle Ages before such rise led to significant water logging and peat growth in this border zone, but the mean groundwater level never reached to above NAP (Dutch Ordnance Datum).

Keywords: Mid-Holocene, moorland pool, Netherlands, soil formation, stagnative podzol, vegetation succession

\section{Introduction}

The Mid- and Late-Holocene landscape evolution of the western part of the Netherlands was dominated by sea level rise and associated processes, such as the formation of estuaries and tidal basins. The 'drowning' of the Pleistocene landscape induced extensive peat growth (Holland Peat), which gradually expanded eastward (Vos, 2015). Rates of sea level rise and peat expansion are largely based on studies of peat deposits overlying compaction-free substrates, such as Pleistocene coversands (e.g. Van de Plassche, 1982; Van de Plassche et al., 2005). Cohen (2005) and Hijma \& Cohen (2011) produced detailed reconstructions of the palaeo-groundwater rise in the coastal prism, including the gradient towards the eastern part of the Rhine-Meuse palaeo-valley, based on such approach.

Het Gooi forms the northwestern extension of the ice-pushed ridge complex of the Utrechtse Heuvelrug. To the west it is flanked by a Holocene peat area. Peat-based evidence on the
Mid- to Late-Holocene groundwater-level rise and associated maximum expansion of the peat is virtually non-existent. Wimmers \& Van Zweeden (1992), for example, assume a rise of the groundwater level to about $3 \mathrm{~m}+\mathrm{NAP}$ (Dutch Ordnance Datum) in the central area of Het Gooi around 1000 BC, but they based this assumption partly on toponyms and on the occurrence of peat of ill-defined origin (e.g. including ombrogenic fens). Moreover, such high groundwater level is in conflict with results from a recent study of the Laarder Wasmeren by Sevink et al. (2013), who showed that in this central part of Het Gooi a highstand of about $2.3 \mathrm{~m}+\mathrm{NAP}$ was reached around $3000 \mathrm{BC}$, with locally open water to that level. The groundwater level subsequently fell to less than $2.0 \mathrm{~m}+\mathrm{NAP}$.

More recent groundwater-fed lakes or groundwater-linked peat deposits above the latter level are not known to occur in this northwestern area, suggesting that later on the groundwater level was lower. This was probably determined by the interplay between the southward development of the Zuiderzee 
and high permeability of its subsoil, being coarse-textured, and highly permeable Pleistocene ice-pushed deposits. The combination may well have resulted in a smaller hydraulic head and thus reduced groundwater rise in the northwestern part of Het Gooi, relative to that described for the Rhine-Meuse area.

\section{The Gijzenveen}

In 2013 a new nature conservation area, called 'Gijzenveen' $\left(52^{\circ} 16^{\prime} 18.26^{\prime \prime} \mathrm{N} ; 5^{\circ} 08^{\prime} 33.01^{\prime \prime} \mathrm{E}\right)$, was created within the municipality of Hilversum. This Gijzenveen (Figs 1 and 2) is situated at the transition between Het Gooi and the Holocene Holland Peat area (Bazelmans et al., 2011), and was studied in detail by Den Haan \& Sevink (2010). Soils in this area had a nutrientrich, largely man-made topsoil, which was removed as part of the ecological restauration of the area, exposing the underlying formations. These consist of a thin layer (up to $1 \mathrm{~m}$ ) of Pleistocene coversand, resting on fluvio-periglacial deposits that are made up of gravelly coarse sand (Den Haan \& Sevink, 2010; Koopman \& Sevink, 2015). The surface of the coversand is slightly inclined to the west and exhibits a shallow, broad depression. The latter is filled with peat, which forms a small eastern extension of the Holland Peat. Fig. 2 shows a map of the area and the location of the depression and thickness of its peat fill.

In the Pleistocene deposits a podzol had formed, which over most of the Gijzenveen area has been extensively truncated in recent times, largely in connection with the construction of earthworks for a small military fortress. The podzol is preserved underneath the peat and in some less truncated higher parts, including a small dike in the southwest. In the latter, the remains of a small and shallow depression in the coversand occur, where this podzol is developed as a hydromorphic humic podzol with a very dense and stagnative Bh horizon. On top of this podzol a c. $25 \mathrm{~cm}$ thick peat sequence is present between 0.65 and $0.40 \mathrm{~m}$-NAP (Fig. 2). In the nearby larger depression with a thick peat fill (Fig. 2), the underlying podzol does not have such a stagnative Bh horizon and coversand is often absent, the podzol then being developed in the fluvio-periglacial deposits. Here, the upper peat strata, which today reach to about $0.5 \mathrm{~m}$ -NAP, contain abundant pyrite and exhibit prominent jarosite and ferrihydrite mottling along cracks and fissures, testifying to a former inundation by seawater from the "Zuiderzee", which at the earliest may have occurred during Late Medieval time (e.g. Vos, 2015). The maximum (ground)water level in the Gijzenveen area was approximately at NAP (for arguments, see below, and Koopman \& Sevink, 2015), evidencing that inundations by the Zuiderzee probably never reached serious dimensions.

In the western border zone of Het Gooi, the land surface has been extensively lowered by extraction of peat and sand (e.g. in the municipalities of 's Graveland and Naarden) or disturbed, leaving the Gijzenveen as one of the few undisturbed areas. The Gijzenveen peat, of which the base at its lowest point lies at approximately $1.3 \mathrm{~m}$-NAP (Fig. 2), thus might provide reliable and unique information on the Mid-Holocene peat expansion in the western border zone of Het Gooi. Since the Gijzenveen area was historically still known as a marsh, the peat might cover a considerable period of time and also record the Late-Holocene environmental history of this transition zone.

\section{Mid- and Late-Holocene soil development}

Podzolisation is the dominant soil-forming process in northwest European coversands. The process started during the Early Holocene. Some disagreement still exists on the age of true podzols', i.e. podzols with a distinct humuspodzol-B (De Bakker \& Schelling, 1989). In Het Gooi the introduction of agriculture took place around $3500 \mathrm{BC}$. It is still widely assumed that concurrent degradation of the forest vegetation into ericaceous heathlands played a decisive role in the genesis of 'true podzols'. Earlier soils would have been less prominently developed and were described as 'moderpodzols', 'acid brown soils' or 'brown forest soils' without a distinct humuspodzol-B (e.g. see Jongmans et al., 2013). However, detailed studies on drift sand complexes in the Laarder Wasmeren area, $7 \mathrm{~km}$ southeast of the Gijzenveen, showed that already before $3000 \mathrm{BC}$ and probably even earlier (before $4000 \mathrm{BC}$ ) prominent humuspodzols had developed in coversands under a predominantly ericaceous vegetation (Sevink et al., 2013). By the Neolithic/Early Bronze age (around $2000 \mathrm{BC}$ ) this process had resulted in the widespread development of such podzols, as evidenced by their occurrence below burial mounds of this age (Doorenbosch, 2013).

Where podzols formed under poorly-drained conditions, they were marked by dispersed organic matter, giving rise to dense and thick, brownish spodic Bh horizons with low permeability. In the Laarder Wasmeren area, pools resulting from local water stagnation on such hydromorphic podzols probably already occurred around 3000 BC (Sevink et al., 2013).

Where well drained, spodic B horizons retained some iron in the form of a Bs horizon as well as iron coatings on sand grains below the Bs horizon. Moreover, they rarely developed a truly stagnative spodic B horizon. The Bs horizon and sand coatings are highly indicative of the current and past position of the GHG (mean highest groundwater level) in the soil profile concerned (e.g. see De Bakker \& Schelling, 1989; Jongmans et al., 2013), since below that GHG level such iron compounds disappear through gleying. This allows for estimation of the maximum groundwater level reached in an area, including the Gijzenveen. In this area, the maximum GHG was found to have reached to about NAP.

The main aims of the present study were to assess the early local and regional vegetation history of this border zone of Het Gooi, in relation to soil development and potential human impact. Additionally, attention is given to the implications of our observations for the reconstruction of sea-level change and 

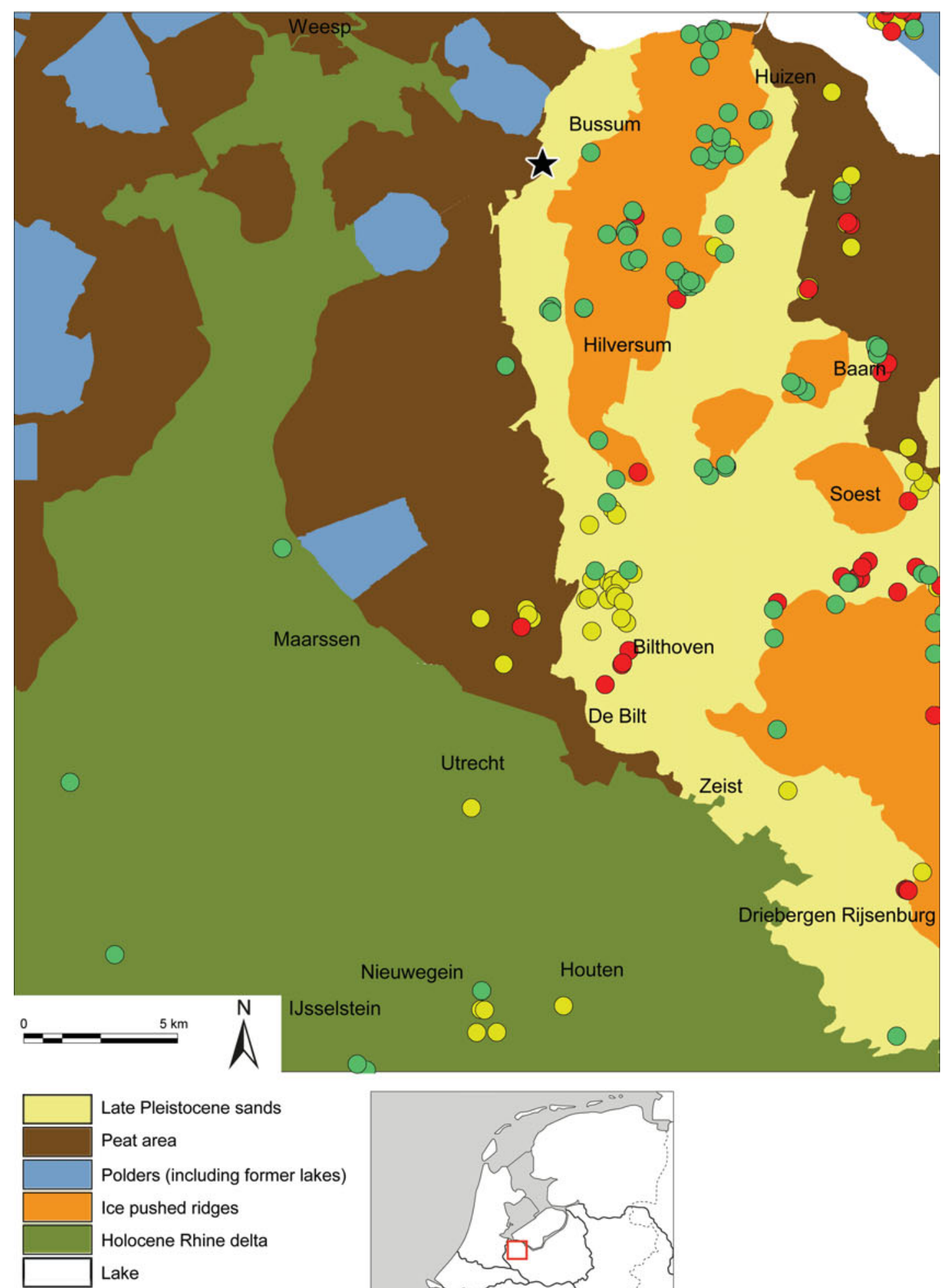

Late Pleistocene sands

Peat area

Polders (including former lakes)

Ice pushed ridges

Holocene Rhine delta

Lake
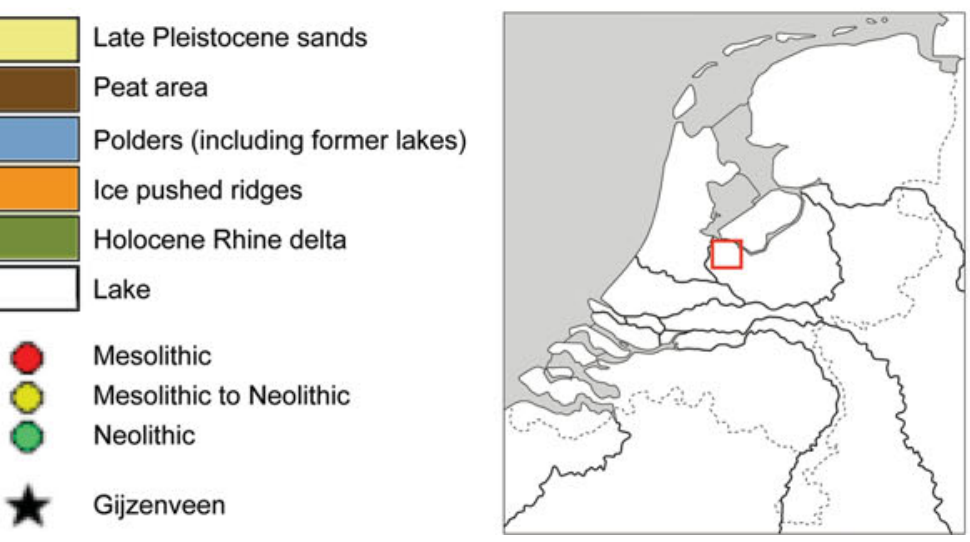

Fig. 1. Current landscapes and location of Mesolithic and Neolithic finds according to Archis, the Dutch archaeological database. 


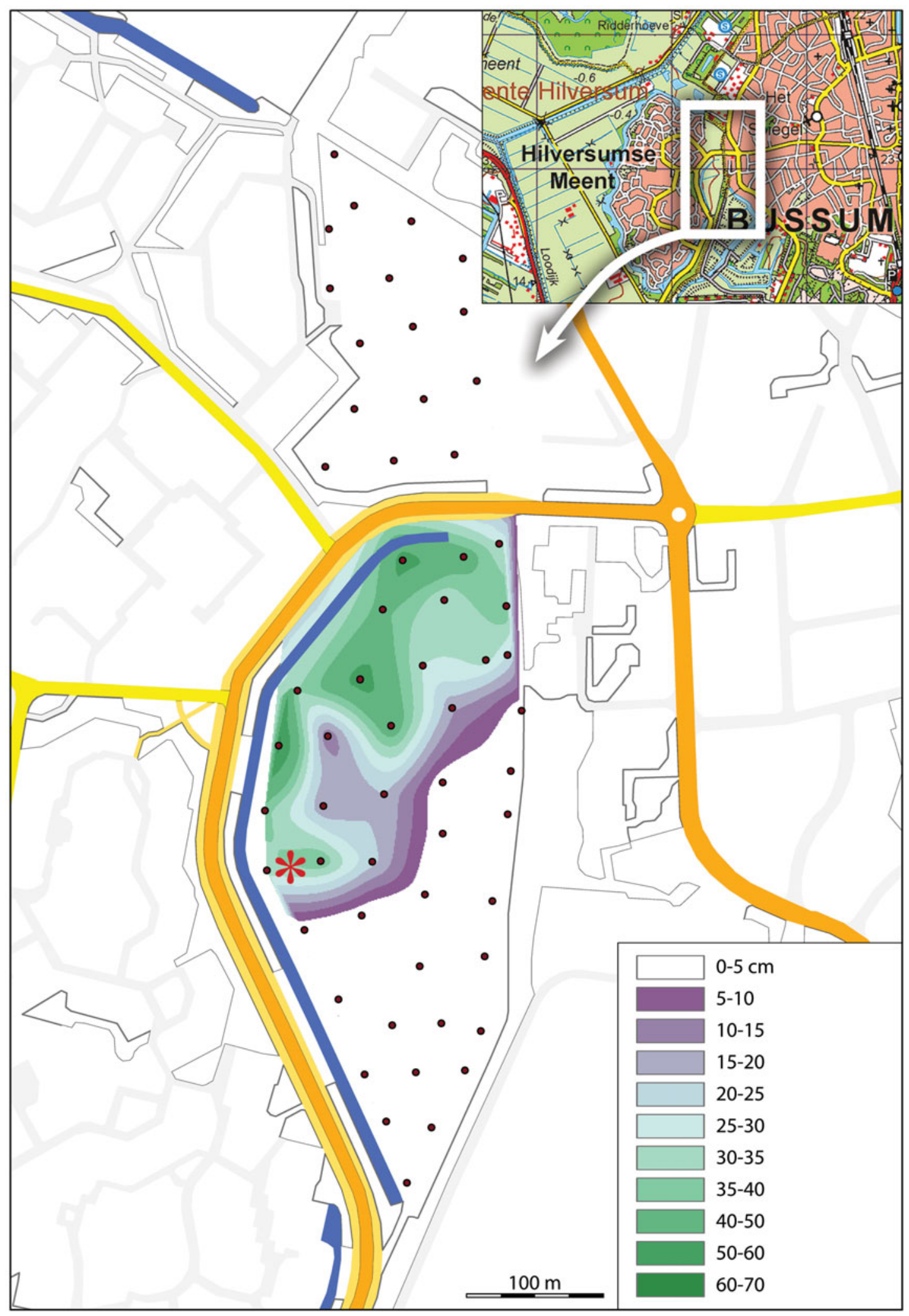

Fig. 2. Map showing the occurrence and thickness of the peat deposit, based on linear interpolation. The sampling location is indicated by $*$ and corings are indicated by black dots. 
Table 1. Description of peat section sampled.

\begin{tabular}{|c|c|c|}
\hline $\begin{array}{l}\text { Depth } \\
\text { (cm below NAP) }\end{array}$ & $\begin{array}{l}\text { Soil } \\
\text { horizon }\end{array}$ & Description \\
\hline $25-39$ & $\mathrm{H}$ & $\begin{array}{l}\text { Very dark brown, non-stratified } \\
\text { peat with inclusions of white } \\
\text { sand } \\
\text { Abrupt transition to underlying } \\
\text { horizon }\end{array}$ \\
\hline $39-65$ & $\mathrm{H}$ & $\begin{array}{l}\text { Finely stratified very dark brown to } \\
\text { dark brown peat, very few } \\
\text { bleached sand grains } \\
\text { Abrupt transition to underlying } \\
\text { horizon }\end{array}$ \\
\hline $65-79$ & $\mathrm{H} / \mathrm{Ah}$ & $\begin{array}{l}\text { Dark brown (moist) to grey (dry) } \\
\text { strongly decomposed peat }(\mathrm{H}) \\
\text { with common bleached sand } \\
\text { grains, changing with depth to } \\
\text { very humic bleached medium } \\
\text { sized sand (Ah) } \\
\text { Gradual transition to underlying }\end{array}$ \\
\hline+79 & $\mathrm{Bh}$ & $\begin{array}{l}\text { Brown, humic, structureless to } \\
\text { massive, medium sand }\end{array}$ \\
\hline
\end{tabular}

associated groundwater level in this hitherto poorly studied part of the Netherlands.

\section{Methods}

The Gijzenveen area was intensively surveyed by coring, paying particular attention to the occurrence and thickness of peat, and to the nature of the Pleistocene deposits underneath this peat. The methods were extensively described by Den Haan \& Sevink (2010), and results have already been summarized above.

In the larger depression, the basis of the peat was not exposed and hard to sample, with strong seepage from the underlying coarse fluvio-periglacial deposits. We therefore decided to sample a well-exposed fresh profile below the dike in the southwest (see Fig. 2), where the peat basis lies at about 0.65 $\mathrm{m}$-NAP. This profile was sampled with a metal box of $50 \times$ $15 \times 10 \mathrm{~cm}$ that was pushed into the profile. A description is given in Table 1 . The top of the metal box was at $33 \mathrm{~cm}-\mathrm{NAP}$.

Twenty-two subsamples, each $1 \mathrm{~cm}$ thick, were taken from the box and analysed for microfossils and macrofossils. Two samples of macrofossils were AMS radiocarbon dated at the Groningen Centre for Isotope Research. The microfossil samples were prepared according to Faegri \& Iversen (1989). The material was embedded in glycerol gelatin on microscopic slides and sealed in with paraffin wax. Microfossils were counted at a magnification of $\times 400$, or $\times 1000$ if necessary. Pollen was iden-
Table 2. Results of radiocarbon dating.

\begin{tabular}{llll}
\hline $\begin{array}{l}\text { Depth } \\
\text { (cm) }\end{array}$ & GrA no. & ${ }^{14}$ C age (BP) & Calibrated age intervals \\
\hline $7+8$ & 62171 & $4490 \pm 35$ & $5299-4983 \mathrm{cal} \mathrm{BP}(3349-3033 \mathrm{cal} \mathrm{BC})$ \\
29 & 62169 & $4875 \pm 35$ & $5698-5488 \mathrm{cal} \mathrm{BP}(3748-3538 \mathrm{cal} \mathrm{BC})$ \\
\hline
\end{tabular}

tified with the keys and illustrations of Moore et al. (1991), Beug (2004) and a pollen reference collection. The upper $5 \mathrm{~cm}$ of the sandy soil (zone A; see below) contained sufficient microfossils for a vegetation reconstruction (cf. Dimbleby, 1985), but the lower $13 \mathrm{~cm}$ of the sampled sequence (38-50 cm depth; 70$83 \mathrm{~cm}-\mathrm{NAP}$ ) was extremely poor in pollen. Apart from pollen grains other microfossils with a characteristic morphology (nonpollen palynomorphs, NPP) were also recorded in the pollen slides. These NPP were described and illustrated by Van Geel (1978), Van Dam et al. (1988), and Van Geel et al. (1980, 1989). Based on studies by the first author most NPP have been shown to be characteristic of specific local habitats (different types of peat and lake deposits, and anthropogenic environments) and therefore they can be used as additional palaeo-environmental indicators. Microfossil slides were counted to a total of at least 250 pollen grains of trees and upland herbs. Herbaceous pollen of swamp and aquatic taxa, spores and NPP were excluded from that sum for percentage calculations. Diagrams were produced using the TILIA program (Grimm, 1992-2004).

For macrofossil analysis, $1 \mathrm{~cm}$ thick samples (each sample had a volume of c. $13 \mathrm{~cm}^{3}$ ) were taken from the same levels as the pollen samples. These samples were immersed in c. 40 $\mathrm{ml} 5 \% \mathrm{KOH}$ and then briefly boiled. Macrofossils were recovered after washing the samples over a $160 \mu \mathrm{m}$ mesh sieve. Fruits, seeds, other plant remains and zoological remains were handpicked from the residue using a stereomicroscope and stored in glycerol until identification (Mauquoy \& Van Geel, 2007). Most fruits and seeds were identified using the catalogue of Cappers et al. (2006) and the reference collections of the University of Amsterdam and the Cultural Heritage Agency (RCE, Amersfoort). Juncus seeds and Poaceae fruits were identified with the key and illustrations of Körber-Grohne (1964). For identification of vegetative plant remains the atlas of Mauquoy \& Van Geel (2007) was used.

\section{Results}

\section{Dating, diagrams and zonation}

The two radiocarbon samples appeared to date from the fourth millenium BC. Results are shown in Table 2. The sample at 29 $\mathrm{cm}$ consisted of seeds of Eleocharis multicaulis and the sample at $7+8 \mathrm{~cm}$ consisted of seeds of Carex rostrata, Sphagnum (opercula) and vegetative remains of Eriophorum vaginatum. 

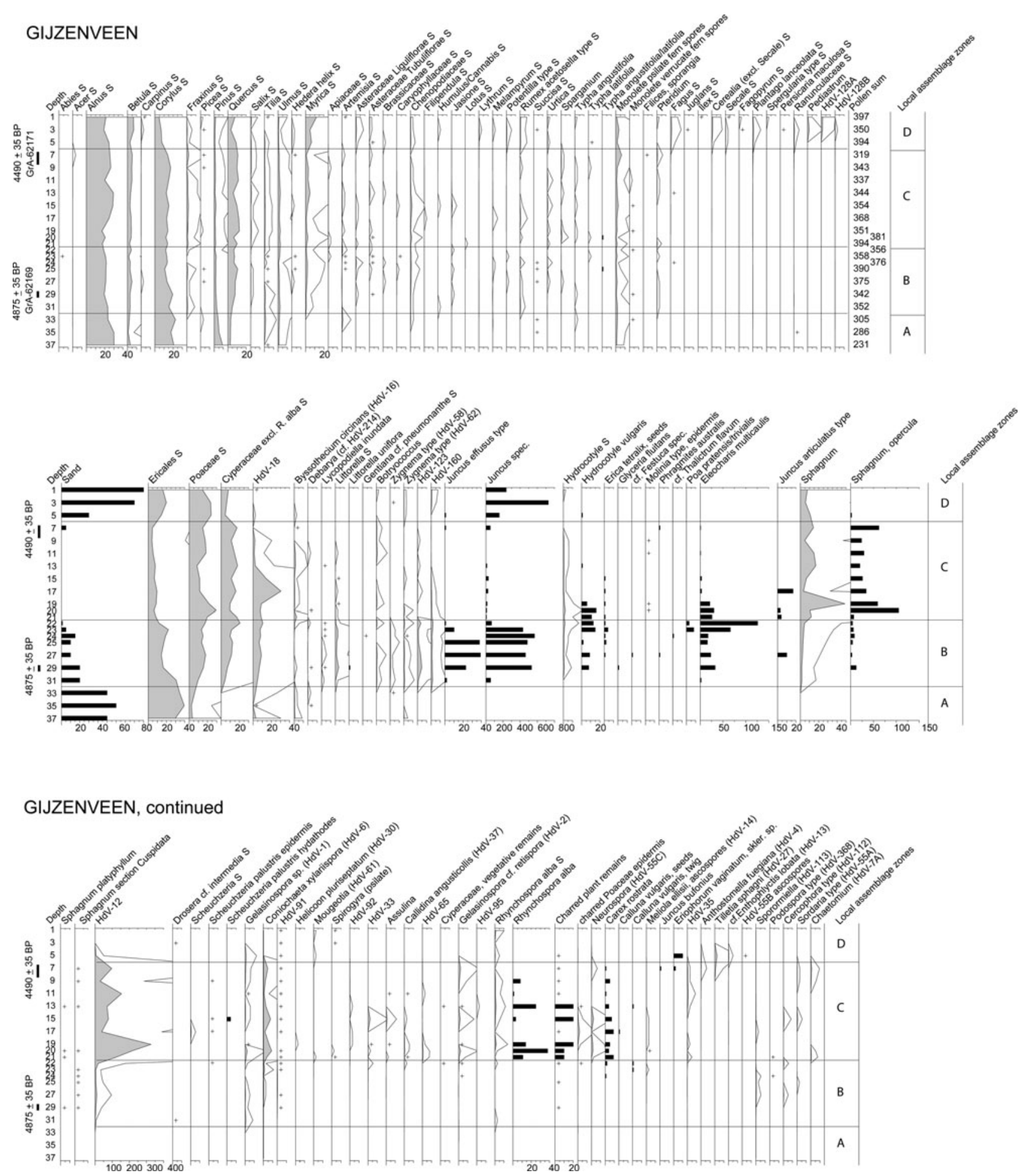

Fig. 3. Gijzenveen diagrams showing regional vegetation history (upper part) and local vegetation succession (middle and lower part). Taxa included in the pollen sum are marked with 'S'. Macrofossils shown as bars; microfossils as curves. For profile description see Table 1.

Regional and local taxa were plotted in separate diagrams, their distinction being based on the ecological range of the various taxa and the presence/absence of macrofossils. Fig. 3 (upper part) shows from left to right: (1) supposed regional arboreal pollen taxa in an alphabetical sequence, (2) herbaceous taxa, also sorted alphabetically, (3) ferns and (4) some taxa that suddenly appeared (zone D) after a hiatus. Fig. 3 (middle and lower part) shows, from left to right, local taxa (combination of microfossils and macroremains) in a more or less chronological sequence of the vegetation succession. The taxa of the regional vegetation did not show major changes during the c. 450 years of organic accumulation, therefore the zonation of Local Assemblage Zones A-D is based on the strictly local vegetation succession. 


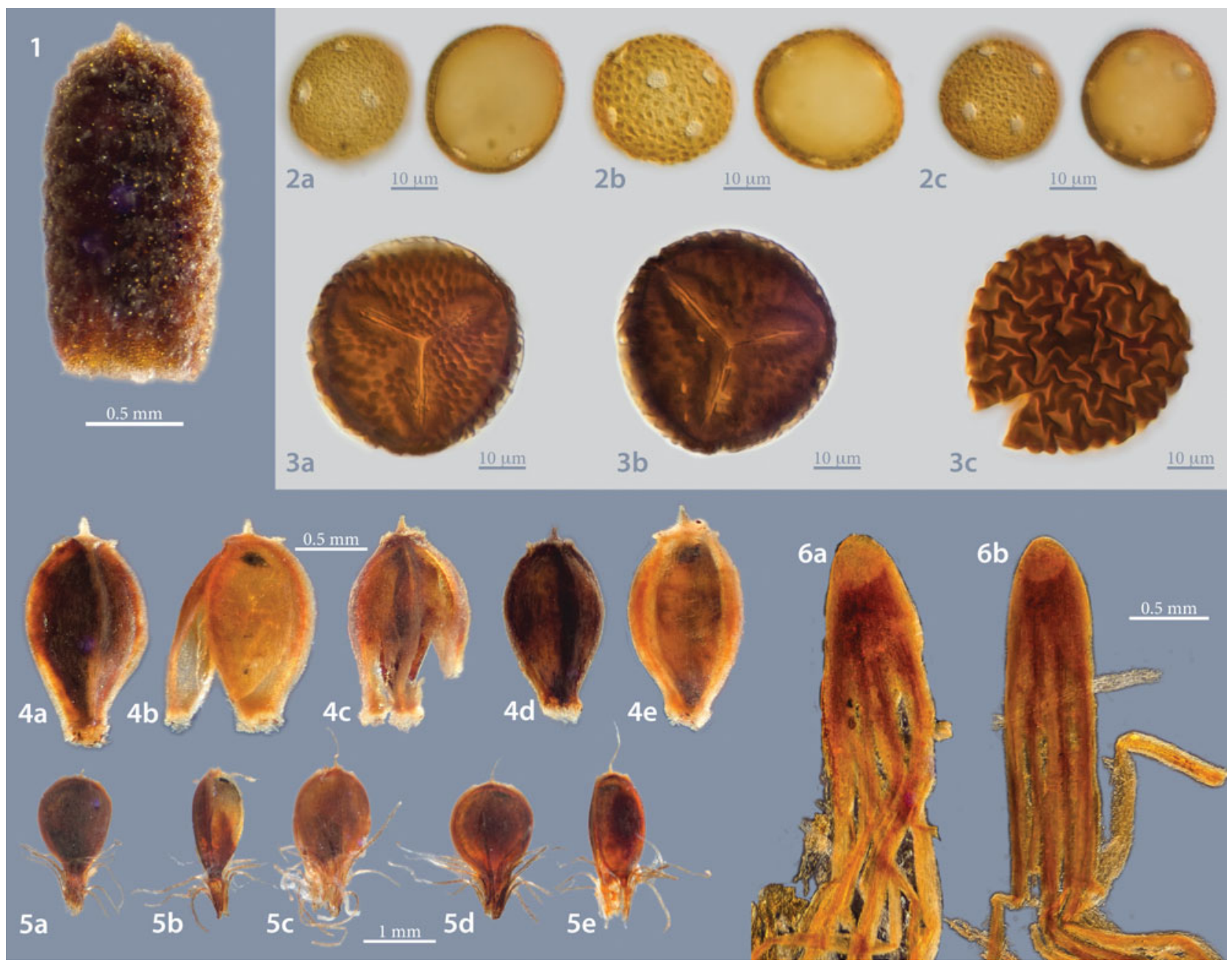

Fig. 4. Selection of macrofossils and microfossils from the Gijzenveen. 1, Littorella uniflora, fruit; 2a-c, Littorella uniflora, pollen; 3a-c, Lycopodiella inundata, spores (proximal and distal views); $4 a-e$, Eleocharis multicaulis, fruits; $5 a-e$, Rhynchospora alba, fruits; $6 a, b$, Scheuchzeria palustris, hydathodes.

\section{Regional vegetation and biostratigraphical dating}

Fig. 3 (upper part) shows the microfossil record of upland taxa, and evidences the continuity in the composition of the regional vegetation. The very low values of Fagus pollen (only two observations) fit well with an early Subboreal (Early Neolithic) age of the deposit. The absence of Plantago species may indicate the absence or low intensity of farming: Plantago lanceolata is a meadow species and Plantago major is an indicator for compacted soils. The high proportion of Corylus pollen within the regional pollen rain points to a relatively open landscape on the sandy soils to the east of the Gijzenveen. The relatively high percentages of Ericales in zone A (later Ericales pollen may come from strictly local Calluna vulgaris and Erica tetralix in the infill of the moorland pool) and the occurrence of, among others, Jasione, Artemisia and other Asteraceae, Rumex acetosella and Pteridium in zones $\mathrm{B}$ and $\mathrm{C}$ also point to a rather open landscape. Nitrophilous 'Chenopodiaceae' (Amaranthaceae with periporate pollen grains), Urtica and spores of coprophilous fungi (Sporormiella, Podospora type, Sordaria type) indicate the presence of herbivore dung. The transition from zone $\mathrm{C}$ to zone $D$ represents a hiatus after which much younger pollen was recorded (see below).

\section{Local vegetation record}

Zone A The predominantly sandy deposit did not contain macrofossils, but the pollen spectra point to a somewhat grassy heathland with Succisa pratensis, preceding the moorland pool phase of zone B. Within heath vegetation Succisa is indicative of relatively base-rich sites with a fluctuating water table.

Zone B Local taxa are Lycopodiella inundata (Fig. 4 (3)), Littorella uniflora (Fig. 4 (2)), and Juncus effusus type (including J. conglomeratus) as well as zygnemataceous spores (filamentous algae HdV-58, HdV-62), Type HdV-160 (Van Dam et al., 1988; Van Geel et al., 2014). Lycopodiella inundata, Littorella uniflora, algae and the increasing organic content of the sediment indicate a rise of the local water table, so that - at least temporarily - shallow, stagnant open water prevailed. 
During summers locally dry conditions may have occurred. A gradient with Eleocharitetum multicaulis (Littorella, Eleocharis multicaulis (Fig. 4 (4)), Hydrocotyle vulgaris) and LycopodioRhynchosporetum (Lycopodiella as well as some Erica tetralix, Drosera intermedia, Gentiana pneumonanthe and Rhynchospora alba, Fig. 4 (5)) is suggested (names of phytosociological units after Schaminée et al., 1995). The former community occupies lower-lying parts than the latter, but both are characteristic of sites inundated in winter and falling dry in summer. The partly minerogenic (sandy) component of the sediment probably originates from erosion of dry soils (open landscape) in the surrounding of the site, being blown into the pool or washed in. Trophic conditions were rather poor. Spores and opercula of Sphagnum point to local occurrence, but Sphagna were not yet important in the local vegetation. Type HdV-123 fungal spores are known from mesotrophic sites (Pals et al., 1980).

Both Littorella uniflora and Lycopodiella inundata are characteristic of mineral soils with a varying amount of organic matter, but without peat formation; both species are unable to compete with Sphagnum due to their very low growth rate. Littorella and Lycopodiella are tolerant of temporary, superficial desiccation and of moderate acidification. Their co-occurrence with the much more robust Juncus effusus/conglomeratus suggests a mosaic of higher and lower vegetation patches.

The shift from a vegetation type with Littorella uniflora and Lycopodiella inundata to a vegetation dominated by Sphagnum and fungal spores specific for a Sphagnum-dominated, raised bog-like habitat is between samples at 22 and $21 \mathrm{~cm}$ depth and therefore a zone boundary is based on that vegetation change. However, Hydrocotyle vulgaris and Eleocharis multicaulis occurred before and after this vegetation shift, apparently because those two species can occur in the moorland pool phase and also in the initial stage of the following Sphagnumdominated vegetation type.

Zone $C$ The transition from zone $B$ to zone $C$ is characterised by a fast change from amphibic, moderately acid, mesotrophic to permanent moist, oligotrophic and strongly acid conditions, whilst the sediment becomes purely organic. In the first stage predominance is taken over by Eleocharis multicaulis, which is more tolerant of acidification than Littorella and Lycopodiella and more competitive with regard to Sphagnum due to vegetative propagation. Hydrocotyle vulgaris shows a somewhat similar behaviour, while Carex rostrata begins to establish itself. A striking decline is shown by Juncus effusus/conglomeratus, suggesting rapid oligotrophication and/or Sphagnum growth. Sphagnum dominance pushes back Eleocharis multicaulis and favours Rhynchospora alba and to a lesser extent Carex rostrata. Phytosociologically speaking Littorelletea (pool) communities are succeeded by Scheuchzerietea communities (permanent local wet conditions). A variety of NPP known for nutrient-poor, ombrotrophic conditions appear, such as Assulina, Callidina angusticollis, Coniochaeta xylariispora (HdV-6), HdV-33, HdV-
35, HdV-65, and HdV-92. The content-free hyalocytes of the Sphagna have a high water storage capacity, and thus stabilise local wet conditions. In addition Sphagnum mosses have the ability to actively acidify their substrate (cation exchange) and to resist decay (Verhoeven \& Liefveld, 1997). The presence of Scheuchzeria palustris (Fig. 4 (6)) points to permanent wet, and still slightly minerotrophic local conditions, but Scheuchzeria with its rhizomes, roots and hydathodes will have got extra nutrients from deeper layers. Superficial fires occurred regularly, as evidenced by charred plant remains and ascospores of Neurospora (HdV-55C) and Gelasinospora (HdV-1 and HdV-2). The fungus Meliola ellisii (HdV-14) is an obligate parasite of Calluna vulgaris, and indeed its presence fits well with the local occurrence of Calluna (Van Geel, 1978).

Zone $D$ The transition from zone $\mathrm{C}$ to zone $\mathrm{D}$ is abrupt. The sediment changes from purely organic peat to rather sandy peat, and the pollen record shows some major changes. The presence of Late-Holocene taxa such as Fagus and the food plants Juglans, Secale and Fagopyrum, which were absent from zone $C$, point to a hiatus at the transition from zone $C$ to zone $D$. A major change in local environmental conditions is reflected by a sharp decline of most of the taxa of nutrient-poor conditions at the end of zone C, while the algae Pediastrum and HdV-128A and HdV-128B indicate eutrophic conditions in zone D. The presence of Fagopyrum pollen most likely points to an age of the 13 th century or later.

\section{Discussion}

From the data above it is clear that the palaeoarchive encountered in the Gijzenveen holds an important hiatus, being a gap between the period before large-scale human impact and the period from the 13th century AD or later. The early phase will be discussed first, followed by the late phase and the associated hiatus.

\section{The early phase}

Holocene podzolisation and the related degradation of the vegetation (towards ericaceous vegetation) and of the landscape (towards the development of active drift sands) are generally considered to be strongly linked to agricultural overexploitation (e.g. see Jongmans et al., 2013), but Sevink et al. (2013) showed that podzolisation, related ericaceous vegetation, and erosion and burial of soils by drift sand had already started in Het Gooi prior to the introduction of agriculture. They observed that a first change from woodland to heathland occurred around 6500 cal BC and that such changes occurred repeatedly. This early soil degradation and associated aeolian activity might be linked to pre-agricultural overgrazing and burning of a still fragile landscape, a conclusion also reached in studies on early 
river dunes (Willemse \& Groenewoudt, 2012) in the eastern Netherlands.

Our Gijzenveen record of a moorland pool, dating from around $3700 \mathrm{cal} \mathrm{BC}$, fits in the landscape development of Het Gooi as reconstructed by Sevink et al. (2013). However, the question arises whether the observed change from woodland to heathland should be considered as a more or less autonomous, natural development (cf. Vera, 2000), or is linked to early human land use, such as grazing by domesticated herbivores or repeated burning.

Holocene soil formation in the coversands of the Gijzenveen area started under well-drained conditions, with sea level still very low (between 5 and $4 \mathrm{~m}-\mathrm{NAP}$, see below). A rising groundwater level and increased seepage from the higher ice-pushed ridges into the lower parts of the landscape, resulting from a combination of sea-level rise, wetter climate and changing vegetation (e.g. see Jongmans et al., 2013), will have led to relatively poorly drained conditions in the lowest parts, and concurrent development towards a hydromorphic, stagnative podzol. For the site studied, with the top of the podzol being at $0.65 \mathrm{~m}-\mathrm{NAP}$, a direct causal relation with sea-level rise is truly unlikely. It is far more probable that this development resulted from the 'drowning' or 'paludification' that has been extensively described for the Pleistocene landscapes of the Netherlands (e.g. Pons, 1992; Fokkens, 1998) and comprises the gradual expansion of a stagnative podzol, and associated development of peatlands and changes in vegetation composition. Whereas such a process explains the development towards a moorland pool, it does not explain the transition from woodland to dry heathland. The question therefore arises whether early human land use might indeed play a role and, consequently, whether indications for such a potential role can be found in the regional archaeological record for the period concerned or in the data from the moorland pool.

The palaeolandscape of the Netherlands has recently been described in considerable detail by Vos (2015). Around 4000 $\mathrm{BC}$ sea level was at about $5 \mathrm{~m}-\mathrm{NAP}$, while around $3000 \mathrm{BC}$ it was still at about $4 \mathrm{~m}$-NAP. Most of the landscape from that time was to disappear under later deposits, except for the somewhat higher parts of the Utrechtse Heuvelrug of which Het Gooi forms the northernmost extension. This implies that the archaeological record is biased towards dry land sites on higher, still more or less intact Pleistocene deposits, while outside that area it is largely a 'hidden record'.

The moorland pool phase of our Gijzenveen record is contemporaneous with the Middle Neolithic Funnel Beaker Culture, which was the first agrarian community in this part of the Netherlands (Bakker, 1979), whereas the earlier heathland phase was coeval with communities of hunter-gatherers with a Mesolithic lifestyle. Recorded archaeological finds documented in the Dutch ARCHIS database are plotted in Fig. 1. In the direct vicinity of the Gijzenveen, traces of human presence are scarce for both the Neolithic and the preceding Mesolithic, in which the bias mentioned above probably plays an important role. In the wider area, on the higher sandy ridges finds are more common, especially those from the Neolithic, testifying to a significant human population in Het Gooi during the periods concerned.

Three Mesolithic sites on the nearest ice-pushed ridge all concern sparse remains of flint, but more substantial finds of this period on the Pleistocene surface are very rare in the Netherlands. Illustrative is the only Mesolithic site in the peaty area to the south of the Gijzenveen, where 32 pieces (both artefacts and waste) of Mesolithic flint tool production were found. The Neolithic site closest to the Gijzenveen has yielded ceramics of the Bell Beaker culture, which is present in several of the nearby sites on the ice-pushed ridge as well. The most substantial remains have been found near Laren, where an excavation in 1960 yielded a house plan and numerous finds belonging to the Funnel Beaker culture. Densities of finds as recorded in the ARCHIS database thus are not indicative of a comparatively high population density, relative to other parts of the Pleistocene Dutch landscape, and thus cannot explain a locally deviating vegetation development.

\section{The early vegetation development}

Rainwater-dependent shallow soft waters (low alkalinity and circumneutral $\mathrm{pH}$ values) in Western Europe are characterised by sandy subsoils and low buffering capacities. The vegetation is often dominated by plant species with an isoetid growth form, such as Littorella uniflora. These pioneer vegetation types are often linked to anthropogenic environments (Arts \& Leuven, 1988). According to Van Dam et al. (1988) bio-communities of isolated moorland pools in the Netherlands, Belgium and northern Germany have been severely impoverished by acidification since the beginning of the 20th century. Many pools developed into Sphagnum bogs, at the expense of aquatic macrophytes. In spite of nature conservation (protection) aimed at preservation, the 'deterioration' of Littorelletea communities proceeds. Wind action (absence of forest) and seasonal changes in water level are essential conditions for the existence and maintenance of pioneer communities. Anthropogenic atmospheric deposition of acidifying components and nutrients played an important role in the alterations of moorland pool communities in historical times (references in Arts \& Leuven, 1988).

The Gijzenveen record shows that during the Mid-Holocene a Littorellion vegetation suddenly acidified and developed into an ombrotrophic Sphagnum bog, but without any indication for nearby human impact. The transition was linked to a decline of groundwater influence and therefore a rainwater dependent vegetation developed. Sphagnum species actively acidify their environment (Clymo, 1963, 1964) and therefore shifts to Sphagnum peat often occur abruptly. 


\section{The hiatus and late phase}

The abrupt transition from zone $\mathrm{C}$ to zone $\mathrm{D}$ clearly coincides with a major change in environmental conditions and also represents a major sedimentary hiatus, the sandy organic deposit of zone $\mathrm{D}$ being of Late Medieval or more recent age. The Hilversumse Meent, of which the Gijzenveen forms part, had been communal grazing land till the mid-19th century and it has never been reclaimed for more intensive land use or peat exploitation (Kos, 2009). It was known as poorly drained peatland from early times and drainage was only slightly improved in the mid-19th century. Because of the presence of a small fortress forming part of the Nieuwe Hollandse Waterlinie (constructed in 1870) more recently drainage was also not seriously improved and has remained poor. With the fortress apparently being the only serious anthropogenic intervention in the area, the hiatus may well be linked to its construction.

\section{Conclusions}

A Mid-Holocene vegetation succession on sandy soil showed a development from a dry heathland on a developing podzol to a vegetation adapted to inundations during winter, brought about by an increasingly stagnative podzol, and to local summer dryness. The situation changed from amphibic, moderately acid, mesotrophic conditions to permanently moist, oligotrophic and strongly acidic conditions, a dominance of Sphagnum and habitat-related non-pollen palynomorphs without clear human interference.

The early occurrence of heathland is in line with observations from other nearby sites (Nederhorst den Berg: Van Geel \& Bos, 2007; Laarder Wasmeren: Sevink et al., 2013) and sheds doubt on the still widely accepted paradigm of the link between early agriculture and the development of open, ericaceous vegetation in the Netherlands (e.g. see Doorenbosch, 2013).

In the fourth millenium BC, the moorland pool and associated peat growth developed independent from sea level. During the Late Holocene groundwater level rose and peat growth started in depressions in the landscape. However, sea-level rise never led to mean groundwater levels above Dutch Ordnance Datum, which is attributed to the combination of a high permeability of the Pleistocene subsoil and a limited distance towards the Zuiderzee, preventing the built-up of a significant coastal prism.

Our results call for attention to the distinction between truly groundwater-controlled peat growth and local peat growth induced by stagnation on impervious soil horizons.

\section{Acknowledgements}

The authors thank Jan van Arkel (IBED) and Menne Kosian (RCE) for help with illustrations. Dmitri Mauquoy (Aberdeen) kindly identified Sphagna. We thank anonymous reviewers for valuable comments and suggestions for improvement.

\section{References}

Arts, G.H.P. \& Leuven, R.S.E.W., 1988. Floristic changes in shallow soft waters in relation to underlying environmental factors. Freshwater Biology 20: 97-111.

Bakker, J.A., 1979. The TRB West Group; Studies in the chronology and geography of the makers of hunebeds and Tiefstich pottery. Sidestone Press(Leiden): 250 pp. http://www.sidestone.com/library/the-trb-west-group.

Bazelmans, J., Van der Meulen, M. Weerts, H. \& Vos, P., 2011. Atlas van Nederland in het Holoceen. Uitgeverij Prometheus (Amsterdam): 96 pp.

Beug, H.J., 2004. Leitfaden der Pollenbestimmung für Mitteleuropa und angrenzende Gebiete. Pfeil (Munich): 542 pp.

Cappers, R.T.J., Bekker, R.M. \& Jans, J.E.A., 2006. Digitale zadenatlas van Nederland. Groningen Archaeological Studies 4. Barkhuis (Eelde): 502 pp. http://dzn.eldoc.ub.rug.nl.

Clymo, R.S., 1963. Ion exchange in Sphagnum and its relation to bog ecology. Annals of Botany 27: 309-324.

Clymo, R.S., 1964. The origin of acidity in Sphagnum bogs. The Bryologist 67: 427-431.

Cohen, K.M., 2005. 3D Geostatistical interpolation and geological interpretation of paleo-groundwater rise in the Holocene coastal prism in The Netherlands. SEPM Special Publication No. 83: 341-364.

De Bakker, H. \& Schelling, J., 1989. Systeem van bodemclassificatie voor Nederland. De hogere niveaus. Pudoc (Wageningen): 209 pp.

Den Haan, M. \& Sevink, J., 2010. Inventarisatie bodemverstoring Koedijkgebied. Rapport in opdracht van het Goois Natuur Reservaat. 16 pp.

Dimbleby, G.W., 1985. The palynology of archaeological sites. Academic Press (London): $168 \mathrm{pp}$.

Doorenbosch, M., 2013. Ancestral heaths; reconstructing the barrow landscape in the central and southern Netherlands. Sidestone Press Dissertations (Leiden): 280 pp. https://openaccess.leidenuniv.nl/handle/1887/22313.

Faegri, K. \& Iversen, J., 1989. Textbook of Pollen Analysis, 4th edn. Wiley (Chichester): $328 \mathrm{pp}$.

Fokkens, H., 1998. Drowned landscape; the occupation of the western part of the Frisian-Drenthian Plateau, 4400 BC-AD 500. Van Gorcum (Assen): 183 pp.

Grimm, E.C. 1992-2004, TILIA, TILIA.GRAPH, and TGView. Springfield, USA.

Hijma, M.P. \& Cohen, K.M., 2011. Holocene transgression of the Rhine rivermouth area, The Netherlands/Southern North Sea: palaeogeography and sequence stratigraphy. Sedimentology 58: 1453-1485.

Jongmans, A.G., Van den Berg, M.W., Sonneveld, M.P.W., Peek, G.J.W.C. \& Van den Berg van Saparoea, R.M., 2013. Landschappen van Nederland. Wageningen Aademic Publishers (Wageningen): 942 pp.

Koopman, S. \& Sevink, J., 2015. Zand in beweging; over Goois stuifzand en stuifzandrestauratie. $66 \mathrm{pp}$. http://www.geologischmuseumhofland.nl/ files/Zand_inbeweging_2015.pdf.

Körber-Grohne, U., 1964. Bestimmungsschlüssel für subfossile Juncus-Samen und Gramineen-Früchte, Probleme der Küstenforschung im südlichen Nordseegebiet 7: 1-47.

Kos, H.A., 2009. Van meenten tot marken: een onderzoek naar de oorspromg en ontwikkeling van de Gooise marken en de gebruiksrechten 
op de gemene gronden van de Gooise markegenoten (1280-1568). Department of History of the Middle Ages, Leiden University Institute for History, Faculty of Humanities, Leiden University Leiden). https://openaccess.leidenuniv.nl/handle/1887/14523.

Mauquoy, D. \& Van Geel, B., 2007. Mire and peat macros. In: Elias, S.A. (ed.): Encyclopedia of Quaternary Science, Volume 3. Elsevier (Amsterdam): 23152336.

Moore, P.D., Webb, J.A. \& Collinson, M.E., 1991. Pollen analysis, 2nd edn. Blackwell (0xford): $216 \mathrm{pp}$.

Pals, J.P., Van Geel, B. \& Delfos, A., 1980. Paleoecological studies in the Klokkeweel bog near Hoogkarspel (prov. of Noord Holland). Review of Palaeobotany and Palynology 30: 371-418. http://dx.doi.org/ 10.1016/0034-6667(80)90020-2.

Pons, L.J., 1992. Holocene peat formation in the lower parts of the Netherlands. In: Verhoeven, J.T.A. (ed.): Fens and Bogs in the Netherlands: Vegetation, History, Nutrient Dynamics and Conservation. Kluwer Academic Publishers (Dordrecht): 7-79.

Schaminée, J.H.J., Weeda, E.J. \& Westhoff, V., 1995. De vegetatie van Nederland 2. Plantengemeenschappen van wateren, moerassen en natte heiden. Opulus Press (Uppsala/Leiden): $360 \mathrm{pp.}$

Sevink, J., Koster, E.A., Van Geel, B. \& Wallinga, J., 2013. Drift sands, lakes, and soils: the multiphase Holocene history of the Laarder Wasmeren area near Hilversum, the Netherlands. Netherlands Journal of Geosciences 92: 243-266.

Van Dam, H., Van Geel, B., Van der Wijk, A., Geelen, J.F.M., Van der Heijden, R. \& Dickman, M.D., 1988. Palaeolimnological and documented evidence for alkalization and acidification of two moorland pools (The Netherlands). Review of Palaeobotany and Palynology 55: 273-316. http://dx.doi.org/10.1016/0034-6667(88)90090-5

Van de Plassche, 0., 1982. Sea-level change and water-level movements in the Netherlands during the Holocene. Mededelingen Rijks Geologische Dienst 36: $1-93$.

Van de Plassche, O., Bohncke, S.J.P., Makaske, B. \& Van der Plicht, J., 2005. Water-level changes in the Flevo area, central Netherlands (5300-1500 BC): implications for relative mean sea-level rise in the Western Netherlands. Quaternary International 133/134: 77-93. http://dx.doi.org/10.1016/j.quaint.2004.10.009.

Van Geel, B., 1978. A palaeoecological study of Holocene peat bog sections in Germany and the Netherlands. Review of Palaeobotany and Palynology 25: $1-120$.

Van Geel, B. \& Bos, I., 2007. Paleo-ecologisch onderzoek naar beginnende Holocene veenvorming bij Abcoude. In: Beenakker, J.J.J.M., Horsten, F.H., De Kraker, A.M.J. \& Renes, H.R. (eds): Landschap in Ruimte en Tijd (Liber Amicorum Guus J. Borger). AKSANT (Amsterdam): 111-121.

Van Geel, B., Bohncke, S.J.P. \& Dee, H., 1980. A palaeoecological study of an upper Late Glacial and Holocene sequence from 'De Borchert', The Netherlands. Review of Palaeobotany and Palynology 31: 367-448. http://dx.doi.org/10.1016/0034-6667(80)90035-4.

Van Geel, B., Coope, G.R. \& van der Hammen, T. 1989. Palaeoecology and stratigraphy of the Lateglacial type section at Usselo (the Netherlands). Review of Palaeobotany and Palynology 60: 25-129. http://dx.doi.org/10.1016/0034-6667(89)90072-9.

Van Geel, B., Heijnis, H., Charman, D.J., Thompson, G. \& Engels, S., 2014. Bog burst in the eastern Netherlands triggered by the $2.8 \mathrm{kyr}$ BP climate event. The Holocene 24: 1465-1477. http://dx.doi.org/10.1177/0959683614544066.

Vera, F.W.M., 2000. Grazing ecology and forest history. CABI Publishing (Wallingford): $528 \mathrm{pp}$.

Verhoeven, J.T.A. \& Liefveld, W.M., 1997. The ecological significance of organochemical compounds in Sphagnum. Acta Botanica Neerlandica 46: 117130.

Vos, P., 2015. Origin of the Dutch coastal landscape. Barkhuis (Eelde): $400 \mathrm{pp}$. Willemse, N.W. \& Groenewoudt, B.J., 2012. Resilience in meta-stable landscapes. The non-linear response of Late Glacial aeolian landforms to prehistoric reclamation along Dutch river valleys. eTopoi Journal for Ancient Studies, Special Volume 3: 1007-1036.

Wimmers, W.H. \& Van Zweeden, R.R., 1992. Archeologische en historischgeografische elementen in een natuurgebied: antropogene achtergronden van de Gooise nauurgebieden. DLO-Staring Centrum (Wageningen): 203 pp. 